\title{
INDUCTION EFFECT OF MICROALGAE SCENEDESMUS DIMORPHUS AGAINST HEMATOLOGY ON MICE (MUS MUSCULUS) SUFFERING ANEMIA DISEASES
}

\author{
ARMAINI ARMAINI*, MARNIATI SALIM, PANJI PRIBADI \\ Department of Chemistry, Faculty of Mathematics and Natural Sciences, Biochemistry Laboratory, Andalas University, Padang 25163, \\ Indonesia. Email: armaini59@gmail.com
}

Received: 18 January 2018, Revised and Accepted: 16 April 2018

\section{ABSTRACT}

Objective: This study aims to investigate the potential of Scenedesmus dimorphus as a cure for aplastic anemia in mice (Mus musculus).

Methods: Fifty male mice divided into five groups, mice suffering anemia due to induction of chloramphenicol. Oral administrated of $S$. dimorphus for 28 days with a dose of $2.5 \mathrm{~g} / 50 \mathrm{ml}, 5.0 \mathrm{~g} / 50 \mathrm{ml}$, and $7.5 \mathrm{~g} / 50 \mathrm{ml}$, respectively, to cure aplastic anemia in mice and samcobion as standard drug.

Results: Induction of chloramphenicol caused the mice to suffering aplastic anemia and weight loss in mice. Biomass of $S$. dimorphus has an effect of against hematological parameters and total blood count estimation. The result shows significant ( $<<0.05$ ANOVA) on weight gain, an increase of erythrocyte counts, and hemoglobin level, whereas an increase of hematocrit and reticulocyte values have non-significant, and a dose of $S$. dimorphus $5.0 \mathrm{~g} / 50 \mathrm{ml}$ were the treatment most effective for anemia in mice.

Conclusion: Based on the results of this study, S. dimorphus biomass has the healing benefit of aplastic anemia due to the administration of chloramphenicol.

Keywords: Scenedesmus dimorphus, Aplastic anemia, Erythrocytes, Hemoglobin, Hematocrit.

(C) 2018 The Authors. Published by Innovare Academic Sciences Pvt Ltd. This is an open access article under the CC BY license (http://creativecommons. org/licenses/by/4. 0/) DOI: http://dx.doi.org/10.22159/ajpcr.2018.v11i7.24825

\section{INTRODUCTION}

Microalga Scenedesmus dimorphus has a high nutritional content, so it is widely used as a supplement to improve health. The nutritional component of $S$. dimorphus consists of a protein with a fairly complete amino acid composition with 9 essential amino acids and 8 non-essential amino acids [1]. Lipid content polyunsaturated chain fatty acids (LC_ PUFA), especially eicosapentaenoic acid (EPA) and docosahexaenoic acid (DHA), useful for the prevention of cardiovascular disease, in humans DHA is important for brain and eye development in infants [2,3] and to support cardiovascular health and DHA is also important for plasma, male and female red blood cells (RBC) [3]. Vitamin B12, Vitamin C, folic acid, and iron are quite high in microalgae [4]. Extracts of bioactive compounds in methanol from $S$. dimorphus have activity as an antioxidant and antibacterial of acne [5].

Anemia is a pathological state in the body characterized by a decrease in hemoglobin (HGB) levels, decreased RBC count, and a decrease in hematocrit (HMT) values that also have an impact on the decreased oxygen transport capacity, cause hypoxia of tissue. Anemia is defined as a reduction in total $\mathrm{RBC}$ mass below normal limits [6,7]. The measurement of RBC mass from anemic patients is usually diagnosed based on a reduction in HMT (the ratio of RBC packed to total blood volume) and blood HGB concentrations to levels below the normal range [8]. The anemia classification is based on the mechanisms and clinical approaches used to classify anemia, according to RBC morphology changes. Morphological characters that provide clues to the etiology include the size of RBC (normocytic, microcytic, or macrocytic); a degree of hemoglobinization, reflected in the color of RBC (normochromic or hypochromic); and shape. To characterize, the type of anemia should be doing the physical examination and laboratory tests, such as evaluation of HMT index, HGB, and red blood [9]. RBC index should include cell count, mean corpuscular volume (MCV), mean corpuscular hemoglobin $(\mathrm{MCH}), \mathrm{MCH}$ concentration (MCHC), and red blood cell distribution width (RDW) $[9,10]$.
Aplastic anemia, a condition in which the erythrocytes and other blood elements are no longer formed, may be primarily due to hereditary but rare. The secondary type is caused by a direct destruction of the bone marrow as a side effect of the drug. Drug-associated aplastic anemia results from hypersensitivity or excessive dose of the drug. Some medications have associations with aplastic anemia, both of which have little effect to severe effect on aplastic anemia disease. A clear link between the use of certain drugs and bone marrow failure problems is still encountered in rare cases. Some of the drugs attributed to aplastic anemia include dose-dependent drugs (cytostatic, gold preparations) and independent dose drugs (chloramphenicol, phenylbutazone, anticonvulsants, and sulfonamides) [11]. Some of the factors that cause, anemia is iron deficiency, bleeding, genetic, bone marrow disorders, Vitamin B12 deficiency, Vitamin C and folic acid, malnutrition, malabsorption, and chronic disease [12]. Anemia currently occurs in patients with hypertension, heart disease, hyperlipidemia, diabetes mellitus, and thyroid patients, which is a further complication of the disease [13]. Anemia is common in acute malaria the effect of combining spirulina powder and bitter extracts reduces parasitemia because the antiparasitic activity of sambiloto and spirulina is beneficial to increase the number of erythrocytes and $\mathrm{Hb}$ in mice infected by Plasmodium berghei [14]. Based on the causal factors of anemia, this study was conducted to utilize $S$. dimorphus microalgae for anti-anemia drugs because these microalgae have nutrient content of iron, folic acid, Vitamin B12, Vitamin C, and DHA which can be used to cure anemia disease. A study demonstrating DHA is important for plasma and male RBC [4], a potential microalgae source of PUFA (LC-PUFA), especially EPA and DHA [15]. S. dimorphus local isolates that have been identified biomolecule [16], and cultivated in mediums with urea nitrogen sources, obtained biomass, a high protein content of $6.75 \%$, consisting of 9 essential amino acids and 8 non-essential amino acids, $16.52 \%$ LC and $2.48 \%$ beta-carotene $[1,17]$. The production of lipids in microalgae is influenced by nitrogen sources in its growth medium, at $S$. dimorphus the use of urea nitrogen sources is much better for lipid production, and S. dimorphus can produce palmitic fatty acid and oleic acid [17]. 


\section{METHODS}

\section{Cultivation of $S$. dimorphus}

S. dimorphus microalgae are obtained from a collection of microalgae in the Biochemistry Laboratory, University of Andalas. The Bold's Basal Medium is used for the cultivation of $S$. dimorphus by modifying the nitrogen source with urea.

\section{Animal}

Adult male mice as experimental animals weighing between 20 and $30 \mathrm{~g}$, which has been acclimatized for 2 weeks, and 50 mice divided into five groups, each group consists of 10 mice.

\section{Experimental design}

The experimental design used in this research is randomized block design. Each treatment group in mice was given a chloramphenicol suspension (dose $1.3 \mathrm{mg} / 20$ g body weight), to make anemia mice, after 14 days administration of chloramphenicol, was discontinued. The treatment group consisted of Group 1 (G1), fed pellets, drinking water and administration of chloramphenicol for 14 days (negative control). Group 2 (G2), fed pellet, drinking water, administration chloramphenicol for 14 days and given the anti-anemia drug (samcobion dose $1.3 \mathrm{mg} / 20$ g body weight) as positive control. Group 3 (G3), fed pellets and drinking water, administration chloramphenicol for 14 days and followed by S. dimorphus microalgae with the dose of $2.5 \mathrm{~g} / 50 \mathrm{ml}$. Group 4 (G4) and Group 5 (G5) were treated the same as with G3, followed by S. dimorphus with the dose of $5 \mathrm{~g} / 50 \mathrm{ml}$ and $7.5 \mathrm{~g} / 50 \mathrm{ml}$, respectively.

Microalga S. dimorphus is administered orally, performed once daily and observations performed on days to $0,14,21$, and 28, against HMT values, HGB, erythrocyte, and reticulocyte (RET).

\section{Blood sample collection}

Blood samples were taken from the tail of mice by tail snipping method and blood samples inserted into a blood tube for the biochemical analysis.

\section{Measurement of mice body weight}

The weight of the mice was performed after chloramphenicol administration from day 0 to day 28 after 2 weeks of acclimation in each treatment group (G1, G2, G3, G4, and G5)

\section{Hematology analysis}

Identification of hematological parameters, consisting of HGB, RBC (erythrocytes), HMT, and RET. Measurements were made using a hematology analyzer. Blood sampling was done by injuring the mice tail vein, then blood coming out of the mice tail was collected in the EDTA tube and analyzed.

\section{Statistical analysis}

The result is expressed as mean \pm standard deviation with the sample $(n=10)$ at $p<0.05$. Statistical analysis of data is done using Microsoft Excel software (Microsoft 1 Excel 2010). Statistical significance was analyzed using two factors with ANOVA replication.

\section{RESULTS}

The influence of $S$. dimorphus on mice body weight and erythrocytes Measurement of body weight in mice was done at every group after induction of chloramphenicol for 2 weeks starting from day 0 after acclimatization until the $28^{\text {th }}$ day. Giving chloramphenicol in mice is $1 \%$ of body weight. The induced effects of chloramphenicol and S. dimorphus administration on mean body weight of mice increased as shown in (Table 1). Mice weight in groups of 1, 2, 3, 4, and 5 increased on 0 day and $7^{\text {th }}$ day, on the $14^{\text {th }}$ day lost weight and next increase on the $21^{\text {st }}$ day and $28^{\text {th }}$ day.

The effect of chloramphenicol on mice causes a decrease in the number of erythrocytes, from day 0 to day 14 , in all treatment groups, the mice are suspected of aplastic anemia, a condition in which erythrocytes and other blood elements are not formed, caused by direct destruction bone marrow as a side effect of the drug. The administration of S. dimorphus at treatment G3, G4, and G5, based on observation day 21 and 28, an increase in the number of erythrocytes in each treatment group, on the 21 st day obtained the number of erythrocytes was $4.92 \pm 0.35,5,28 \pm 0$, 38 , and $5,05 \pm 0,41$ (million $/ \mu \mathrm{l}$ ), respectively and at day 28 , obtained $5,55 \pm 0,54,5,93 \pm 0,11$, and $5,33 \pm 0.35$ (million / $\mu \mathrm{l}$ ), respectively, and the greatest increase in erythrocytes in the treatment of G4 (Table 1).

Based on statistical test results using ANOVA to observe the effect of chloramphenicol and S. dimorphus on each treatment group (G1 - G5) to body weight up to day 28 there was a significant difference between the treatments at $p<0.05$ and the number of erythrocytes in the mice between the groups treatment on observation days 0 to 28 there was a significant difference $(\mathrm{p}<0.05)$ as shown in Table 1.The Duncan test was then performed to see the difference between treatment groups in body weight and the number of erythrocytes from mice. Significant differences were seen in G4 treatments with $S$. dimorphus in a dose of $5.0 \mathrm{~g} / 50 \mathrm{ml}$

\section{The influence of $S$. dimorphus on HGB}

Results of observations from days 0 to 28 in each treatment group were obtained, HGB values decreased from day $7^{\text {th }}$ to $14^{\text {th }}$ day in all groups, to below normal limits and backup to normal on day 21 and 28. The HGB value increased after the $14^{\text {th }}$ day in G4, the highest among all treatments, due to $S$. dimorphus administration, at a dose of $5.0 \mathrm{~g} / 50 \mathrm{ml}$ is an effective dose to cure anemia. The administration of an anti-anemia (samcobion) drug in mice (G2 treatment) increased HGB values above the normal limits on the $21^{\text {st }}$ and $28^{\text {th }}$ day, respectively, $13.45 \pm 0.65 \mathrm{~g} / \mathrm{dl}$ and $13.86 \pm 0.95 \mathrm{~g} / \mathrm{dl}$, but the value was lower than that of $S$. dimorphus at all treatment doses. The effective dose of $S$. dimorphus administration was $5.0 \mathrm{~g} / \mathrm{ml}$ on days 21 and 28 in HGB values of $14.80 \pm 0.67 \mathrm{~g} / \mathrm{dl}$ and $15.35 \pm 0.91 \mathrm{~g} / \mathrm{dl}$, respectively. Based on these observations, it can be concluded that administration of $S$. dimorphus is more effective for curing anemia than with anti-anemia treatment (Table 2).

The results of a statistical test using ANOVA to see the effect of $S$. dimorphus microalgae in each treatment group on $\mathrm{HGB}$, it can be interpreted that the HGB of mice between groups of treatment giving S. dimorphus, significantly different $(\mathrm{p}<0.05)$, as shown in Table 2 . Further with Duncan test, to see the differences between treatment groups for HGB of mice. Significant differences were seen in G4 treatments, with S. dimorphus microalgae given in dose $5.0 \mathrm{~g} / 50 \mathrm{ml}$.

\section{The effect of $S$. dimorphus against of HMT value}

The chloramphenicol induction of $1.3 \mathrm{mg} / \mathrm{g}$ body weight resulted in a gradual decrease in HMT values start of day 7 , and the most significant decrease occurred on day 14, and after administration of suspension S. dimorphus and samcobion drug, a caused increased HMT values in all groups of mice. The highest HMT values were seen in G4 (Table 3).

In this study, on 0 days, all animals under normal circumstances are characterized by HGB levels, and HMT values are in the normal range. In the negative control group (G1), only given of chloramphenicol suspension for 14 days, obtained a decrease in HMT value, and on days 21 and 28 showed a slight increase HMT values in mice (Table 3). Based on the results of the ANOVA test, to observe the effect of S. dimorphus on the HMT value on the groups (G3, G4 and G5) to observations from day 0 to 28 there was no significant difference in each treatment group at $\mathrm{p}<0.05$.

\section{The influence of $S$. dimorphus against the number of RET}

Chloramphenicol decreased the number of RET on observation from days 0 to day 14 , where on day 0 treatment, the normal RET counts, values were between $0.70 \pm 0.10$ and $0.74 \pm 0.08 \%$ (Table 4 ), based on the WHO reference normal range of RET $0.5-1.5 \%$. The administration of chloramphenicol causes a decrease in the number of RET on day 14 is in the range of $0.3 \pm 0.07-0.4 \pm 0.24 \%$, this value is below normal conditions compared to the normal threshold in accordance with the 
Table 1: Mean body weight and number of erythrocytes of mice on observation days 0-28

\begin{tabular}{|c|c|c|c|c|c|}
\hline \multirow[t]{2}{*}{ Treatment } & \multirow[t]{2}{*}{ Mean of body weight (g) } & \multicolumn{4}{|c|}{ Number of erythrocytes (million/ $\mu \mathrm{L}$ ) on observation days } \\
\hline & & $\mathbf{0}$ & 14 & 21 & 28 \\
\hline Negative control (G1) & $33.44 \pm 0.383^{\mathrm{a}}$ & $5.62 \pm 0.39^{\mathrm{a}}$ & $4.39 \pm 0.16^{\mathrm{b}}$ & $4.59 \pm 0.12^{\mathrm{a}}$ & $4.89 \pm 0.88^{\mathrm{b}}$ \\
\hline Positive control (G2) & $32.92 \pm 0.383^{\mathrm{a}}$ & $5.61 \pm 0.53^{\mathrm{a}}$ & $4.20 \pm 0.74^{\mathrm{b}}$ & $4.97 \pm 0.38^{\mathrm{a}}$ & $4.97 \pm 0.04^{\mathrm{b}}$ \\
\hline Dose $2.5 \mathrm{~g} / 50 \mathrm{~mL}(\mathrm{G} 3)$ & $32.06 \pm 1.535^{\mathrm{b}}$ & $5.61 \pm 0.53^{\mathrm{a}}$ & $4.32 \pm 0.60^{\mathrm{b}}$ & $4.92 \pm 0.35^{\mathrm{a}}$ & $5.55 \pm 0.54^{\mathrm{b}}$ \\
\hline Dose $5.0 \mathrm{~g} / 50 \mathrm{~mL}(\mathrm{G} 4)$ & $34.24 \pm 0.758^{\mathrm{ab}}$ & $5.67 \pm 0.24^{\mathrm{a}}$ & $4.36 \pm 0.11^{\mathrm{b}}$ & $5.05 \pm 0.38^{\mathrm{ab}}$ & $5.33 \pm 0.11^{\mathrm{ab}}$ \\
\hline Dose $7.5 \mathrm{~g} / 50 \mathrm{~mL}$ (G5) & $33.50 \pm 1.097^{c}$ & $5.67 \pm 0.24^{\mathrm{a}}$ & $4.36 \pm 0.23^{\mathrm{b}}$ & $5.05 \pm 0.41^{\mathrm{a}}$ & $5.33 \pm 0.35^{b}$ \\
\hline
\end{tabular}

Table 2: Mean HGB levels of mice between treatments on observation days to 0-28

\begin{tabular}{|c|c|c|c|c|}
\hline \multirow[t]{2}{*}{ Treatment } & \multicolumn{4}{|c|}{ HGB (g/dL) on observation days } \\
\hline & $\mathbf{0}$ & 14 & 21 & 28 \\
\hline Negative control (G1) & $13.15 \pm 0.98^{\mathrm{a}}$ & $11.50 \pm 1.02^{\mathrm{b}}$ & $12.62 \pm 0.31^{\mathrm{a}}$ & $13.26 \pm 0.66^{\mathrm{b}}$ \\
\hline Positive control (G2) & $15.65 \pm 1.06^{\mathrm{a}}$ & $11.71 \pm 1.88^{b}$ & $13.45 \pm 0.65^{\mathrm{a}}$ & $13.86 \pm 0.95^{b}$ \\
\hline Dose $2.5 \mathrm{~g} / 50 \mathrm{~mL}(\mathrm{G} 3)$ & $15.29 \pm 0.90^{\mathrm{a}}$ & $11.68 \pm 0.90^{\mathrm{b}}$ & $14.28 \pm 0.85^{\mathrm{a}}$ & $14.89 \pm 1.21^{b}$ \\
\hline Dose $5 \mathrm{~g} / 50 \mathrm{~mL}$ (G4) & $15.18 \pm 0.55^{a}$ & $11.71 \pm 0.86^{b}$ & $14.80 \pm 0.67^{\mathrm{ab}}$ & $15.35 \pm 0.91^{\mathrm{ab}}$ \\
\hline Dose $7.5 \mathrm{~g} / 50 \mathrm{~mL}$ (G5) & $15.10 \pm 0.68^{\mathrm{a}}$ & $11.49 \pm 0.91^{\mathrm{b}}$ & $13.38 \pm 0.53^{\mathrm{a}}$ & $13.48 \pm 1.00^{\mathrm{b}}$ \\
\hline
\end{tabular}

WHO criteria, anemia is defined as an HGB level of $<13 \mathrm{~g} / \mathrm{dl}$ for men and $<12 \mathrm{~g} / \mathrm{dl}$ for women. Data expressed mean \pm SD (n=10). SD: Standard deviation,

HGB: Hemoglobin ${ }^{\mathrm{ab}} \mathrm{A}$ statistically significant differences $(\mathrm{p}<0.05)$

Table 3: The value of HMT on mice between groups on observation days 0-28

\begin{tabular}{|c|c|c|c|c|}
\hline \multirow[t]{2}{*}{ Treatment } & \multicolumn{4}{|c|}{ HMT values (\%) on observation days } \\
\hline & $\mathbf{0}$ & 14 & 21 & 28 \\
\hline $\begin{array}{l}\text { Negative } \\
\text { control (G1) }\end{array}$ & $56.50 \pm 0.76$ & $56.01 \pm 1.18$ & $58.28 \pm 0.78$ & $59.48 \pm 0.28$ \\
\hline $\begin{array}{l}\text { Positive } \\
\text { control (G2) }\end{array}$ & $59.98 \pm 4.63$ & $56.20 \pm 2.03$ & $63.01 \pm 1.88$ & $63.70 \pm 0.86$ \\
\hline $\begin{array}{l}\text { Dose } 2.5 \mathrm{~g} / 50 \mathrm{~mL} \\
\text { (G3) }\end{array}$ & $59.47 \pm 2.04$ & $56.39 \pm 4.07$ & $63.46 \pm 1.45$ & $64.42 \pm 3.41$ \\
\hline $\begin{array}{l}\text { Dose } 5.0 \mathrm{~g} / 50 \mathrm{~mL} \\
\text { (G4) }\end{array}$ & $59.98 \pm 3.53$ & $56.87 \pm 4.42$ & $64.84 \pm 2.71$ & $65.24 \pm 2.57$ \\
\hline $\begin{array}{l}\text { Dose } 7.5 \mathrm{~g} / 50 \mathrm{~mL} \\
\text { (G5) }\end{array}$ & $60.51 \pm 3.04$ & $56.01 \pm 7.01$ & $59.66 \pm 3.25$ & $60.79 \pm 1.97$ \\
\hline
\end{tabular}

Data expressed mean \pm SD (n=10). SD: Standard deviation, HMT: Hematocrit

Table 4: The number of RET between treatments on observation days 0-28

\begin{tabular}{lllll}
\hline \multirow{2}{*}{ Treatments } & \multicolumn{4}{c}{ The number of RET (\%) on observation days } \\
\cline { 2 - 5 } & $\mathbf{0}$ & $\mathbf{1 4}$ & $\mathbf{2 1}$ & $\mathbf{2 8}$ \\
\hline $\begin{array}{l}\text { Negative } \\
\text { control (G1) }\end{array}$ & $0.72 \pm 0.08$ & $0.40 \pm 0.07$ & $0.58 \pm 0.08$ & $0.7 \pm 0.07$ \\
$\begin{array}{l}\text { Positive } \\
\text { control (G2) }\end{array}$ & $0.70 \pm 0.12$ & $0.36 \pm 0.08$ & $0.50 \pm 0.07$ & $0.72 \pm 0.08$ \\
$\begin{array}{l}\text { Dose } 2.5 \mathrm{~g} / 50 \mathrm{~mL} \\
\text { (G3) }\end{array}$ & $0.70 \pm 0.10$ & $0.30 \pm 0.07$ & $0.60 \pm 0.10$ & $0.96 \pm 0.11$ \\
$\begin{array}{l}\text { Dose } 5.0 \mathrm{~g} / 50 \mathrm{~mL} \\
\text { (G4) }\end{array}$ & $0.72 \pm 0.08$ & $0.36 \pm 0.08$ & $0.80 \pm 0.07$ & $1.18 \pm 0.21$ \\
$\begin{array}{l}\text { Dose } 7.5 \mathrm{~g} / 50 \mathrm{~mL} \\
\text { (G5) }\end{array}$ & $0.74 \pm 0.08$ & $0.42 \pm 0.04$ & $0.74 \pm 0.05$ & $0.98 \pm 0.21$ \\
\hline
\end{tabular}

WHO reference. The administration of $S$. dimorphus may increase the number of RET on day 21 and 28, respectively, with a range of $0.50 \pm 0.07-0.80 \pm 0.07 \%$ and $0.70 \pm 0.07-1.18 \pm 0.21 \%$ (Table 4 ).

The Statistical test using ANOVA to observe the effect of S dimorphus on the number of RET in each treatment group (G3, G4 and G5) on observation from day 0 to 28 , there was no significant difference at $\mathrm{p}<0,05$.
Estimated complete blood count, consisting of RBC, HGB, MCH, MCHC, HMT, RET, MCV, and RDW was determined to identify anemia (Table 5).

\section{DISCUSSION}

Aplastic anemia is expressed as severe hematologic syndrome, characterized by apical bone marrow associated with peripheral pancytopenia, caused by the destruction of hematopoietic cells in the bone marrow and possibly causing bone marrow failure. Aplastic anemia can be caused by several factors such as autoimmune disease and exposure to external / environmental factors, administration of drugs such as chloramphenicol, severe deficiency (vitamin B, folic acid and iron), pregnancy, or, idiopathic. The theory of autoimmune hypotheses is commonly accepted, namely, the theory that states the destruction of hematopoietic cells by the immune mechanism. Based on the results obtained, weight loss of mice on the 7th day after administration of chloramphenicol is the induced effect of chloramphenicol on mice, causing mice to suffer from aplastic anemia. Aplastic anemia can occur because chloramphenicol functions to suppress the bone marrow [9], resulting in reproductive inhibition and proliferation of bone marrow stem cells against all red blood cell components resulting in aplastic anemia in mice causing weight loss [18]. The administration of S. dimorphus weight gain of mice suffering from aplastic anemia on day 14 to day 28 , to achieve near normal weight, because $\mathrm{S}$. dimorphus can boost the immune system and repair the damage and proliferation of stem cells, bone marrow and all RBC components, so that body weight gradually improves, as is the case with Spirulina can improve the ability to correct anemia and characterized by increased IDO activity and white blood cell count [19].

Induction of chloramphenicol to mice causes a decrease in the amount of erythrocytes in all treatments occurring on day 14 after chloramphenicol administration, a decrease in the amount of erythrocytes leading to aplastic anemia. Aplastic anemia results from decreased RBC production, no young erythrocytes and young leukocytes in peripheral blood, due to hematopoietic injury, which occurs due to impaired bone marrow failure [20].

The administration of $S$. dimorphus may increase the number of erythrocytes on days 21 and 28 in all treatments. The highest increase of erythrocytes occurs in Group 4; this is because $S$ dimorphus can function as an immune stimulator to boost the immune system, thus healing the hematopoietic injury and overcoming bone marrow failure, increasing the stimulation of erythropoietin hormone secretion, and 
Table 5. Estimation of complete blood count on mice of suffering anemia treated with S. dimorphus at optimal concentration

\begin{tabular}{lllllllll}
\hline Observation days & RBC (million/ $\boldsymbol{\mu l})$ & HGB (g/d) & MCH (pg) & MCHC (\%) & HMT (\%) & RET (\%) & MCV (fl) & RWD (\%) \\
\hline 0 & 5.62 & 15.18 & 27.01 & 25.35 & 59.98 & 0.72 & 106.72 & 3.29 \\
14 & 4.29 & 11.71 & 27.29 & 30.08 & 56.87 & 0.36 & 132.56 & 3.33 \\
21 & 5.28 & 14.8 & 28.03 & 22.82 & 64.84 & 0.8 & 122.80 & 2.20 \\
28 & 5.93 & 15.35 & 25.88 & 23.52 & 65.24 & 1.18 & 111.01 & 2.31 \\
\hline
\end{tabular}

RBC: Red blood cells, HGB: Hemoglobin, MCH: Mean corpuscular hemoglobin, MCHC: Mean corpuscular hemoglobin concentration, HMT: Hematocrit, RET: Reticulocyte, MCV: Mean corpuscular volume

intake containing iron, folic acid, and Vitamins B12 as maturation of RBC. Aplastic anemia, drug-related occurs due to hypersensitivity or excessive doses of this drug cause a condition where young erythrocytes and young leukocytes are not found in peripheral blood so that erythrocytes and other blood elements are no longer formed. The secondary type is caused by the direct destruction of the bone marrow as a side effect of the drug [21,22]. Some medications are associated with aplastic anemia, including chloramphenicol.

Based on the observations that started from day 0 to day 28 , there was a decrease of HGB from day 7 to day 14 in all treatment groups. The induction of chloramphenicol causes anemia of the mice because chloramphenicol has a toxic effect on mitochondria, it binds to mitochondria, inhibits the formation of inner membrane enzymes by inhibiting peptidyl transferase, which is necessary for peptide bond formation. The emphasis of erythroid, caused by the inhibition of ferrochelatase, is an inner membrane enzyme, so the synthesis of HGB is inhibited as a result of the direct toxic effects on normal erythrocyte circulation in cells with certain enzyme defects, and with some unstable HGB, or through immune mechanisms [21,22]. Administration of anti-anemia drugs (samcobion) may increase the HGB to normal limits, but $S$. dimorphus administration is more effective than anti-anemic drugs. S. dimorphus can increase the synthesis of HGB because it has iron content, vitamin B12, folic acid, and protein.

The effect of chloramphenicol induction on HMT value starting on day 7 was a decrease of HMT value and a considerable decrease occurred on the 14th day of observation. Administration of anti-anemia drugs (samcobion) increased HMT values this also occurs in normal control on days 21 and 28. This increase in positive control occurred due to the ability of self to restabilize, excitation by the hormone erythropoietin produced by the kidney in a hypoxic state. Drug-induced hematological syndromes such as chloramphenicol are mediated by various mechanisms, including immune mechanisms, interactions with enzymatic pathways, and direct inhibition of hematopoiesis [23]. While in the group of mice given a suspension of microalgae $S$. dimorphus and samcobion saw a much higher increase than the positive control group, but non-significant between treating all groups. That means $S$. dimorphus as nutraceutical can increase HGB levels and HMT values by improving bone marrow, stimulating secretion of erythropoietin hormone and intake iron, folic acid, Vitamin B12, which is contained in S. dimorphus as a maturation of RBC [18, 24]. The number of RET is used to estimate the effective rate of erythropoiesis [25].

Induction of chloramphenicol causes a decrease in RET count up to $14^{\text {th }}$ days as a result of chloramphenicol, where RET are released prematurely from the bone marrow to the blood circulation. Decreased the number of RET reflects decreased RBC production, which can occur due to aplastic anemia or bone marrow failure syndrome. The administration of $S$. dimorphus can increase the number of RET from day 21 to day 28 to normal limits this is due to the ability of S. dimorphus to stimulate effective erythropoiesis and helps repair bone marrow [26]. The number of RET provides indirect insight into bone marrow conditions associated with low RBC production or accelerated RBC damage. The absolute RET count is the number of RET in the blood volume, [26] which is a marker of RBC production [27]. The RET is immature but have enucleated, erythrocyte cells in the presence of residual detectable RNA, resulting in HGB despite enucleation [28].

\section{CONCLUSION}

The induction of Chloramphenicol leads to weight loss of mice, and a decrease in hematologic value (RBC, HGB, HMT, and RET), this is because chloramphenicol can cause bone marrow disorders, resulting in aplastic anemia in mice. The administration of S. dimorphus in male mice (Mus musculus) increased weight, RBC, and HGB in each treatment group significantly. Increased HMT and RET were not significant between treatments. The treatment of $S$. dimorphus is much better than using an anti-anemic drug. Based on the results of the study, $S$. dimorphus has benefit to cure anemia.

\section{ACKNOWLEDGMENT}

The authors are grateful to the PNBP of the Faculty of Mathematics and Natural Sciences. Andalas University, which has funded this research in accordance with Research Contract Number: 01/UN.16.03.SPP/ FMIPA/2017.

\section{REFERENCES}

1. Armaini A, Salim M, Rinaldi R. Influence of urea concentration on biomass, pigment, lipid and protein content of Scenedesmus dimorphus microalgae. Pharma Chem J 2016;8:27-37.

2. Arterburn LM, Hall EB, Oken H. Distribution, interconversion, and dose response of $\mathrm{n}-3$ fatty acids in humans. Am J Clin Nutr 2006;83:1467-76.

3. Bradbury, J. Docosahexaenoic acid (DHA): An ancient nutrient for the modern human brain. Rev Nutr 2011;3:529-54.

4. Arterburn LM, Oken HA, Hall HB, Hamersley J, Guratko CN, Hoffman JP. Algal-oil capsules and cooked salmon: Nutritional equivalent sources of docosahexaenoic acid. J Am Diet Assoc 2008;108:1204-9.

5. Amri E, Dharma A, Armaini A, Tjong DH. Screening anti-acne potency of microalgae: Antibacterial and antioxidant activities. Pharm Chem 2017;9:28-31.

6. World Health Organization. Use of Glycated Hemoglobin (HbA1c) in the Diagnosis of Diabetes Mellitus (Abbreviated Report of a WHO Consultation); 2011.

7. American Diabetes Association. Standards of medical care in diabetes. Diabetes Care 2013;36 Suppl 1:S11-66.

8. Abbas Ak, Fausto N, Aster J. Robins and Cotran, Pathologic Basis of Disease. $8^{\text {th }}$ ed. Ch. 14. Philadelphia, PA: Saunders; 2000.

9. Lu J, Basu A, Melenhorst J, Young NS, Brown GE. Analysis of T-cell repertoire in hepatitis associated aplastic anemia. Blood 2004; 103:4588-93.

10. Khan KS, Wojdyla D, Say L, Gülmezoglu AM, Van Look PF. WHO analysis of causes of maternal death: A systematic review. Lancet 2006;367:1066-74.

11. Shadduck RG. Aplastic Anemia. In: Beuttler E, Coller BS, Lichtman M, Gipps TJ, editors. Williams Hematology. $6^{\text {th }}$ ed. USA: McGraw-Hill; 2001. p. 504-23.

12. LanzGowsky P. Iron Deficiency Anemia. Pediatric Hematology and Oncology. Edisi Ge-2. New York: Churchill Livingstone Inc.; 1995. p. 35-50.

13. Gandasamy G, Amrita P, Anjana S, Sebastian AC, Rajagopal SS, Ramanathan SG. Epidemiological study of prevalence of anemia and associated risk factors in a rural community; A home-based screening. Asian J Pharm Clin Res 2017;10:307-9.

14. Gusmardi G, Elya B, Wahyuni T, Paramita RI. Combination of sambiloto (Andrographis paniculata (Burm.F.) Nees) extractand spirulina (Arthrospira platensis Gomont) to prevent anemia in mice infected WITH Plasmodium berghei Anka. Asian J Pharm Clin Res 2017;10:269-73. 
15. Yang HL, Lu CK, Chen SF, Chen YM, Chen YM. Isolation and characterization of taiwanese heterotrophic microalgae: Screening of strains for docosahexaenoic acid (DHA) production. Mar Biotechnol (NY) 2010;12:173-85.

16. Chaidir Z, Fadjria N, Armaini, Zainul R. Isolation and molecular identification of freshwater microalgae in maninjau lage west Sumatera. Pharm Lett 2016;8:177-87.

17. Rinaldi R, Armaini, Salim M. A selection of nitrogen source for biomass and lipid production of Scenedesmus dimorphus microalgae. Res J Pharm Biol Chem Sci 2015;6:143-7.

18. Young NS, Scheinberg P, Calado RT. Aplastic anemia. Curr Opin Hematol 2008;15:162-8.

19. Selmi C, Leung PS, Fischer L, German B, Yang CY, Kenny TP, et al. The effects of spirulina on anemia and immune function in senior citizens. Cell Mol Immunol 2011;8:248-54.

20. English E, Idris I, Smith G, Dhatariya K, Kilpatrick ES, John WG, et al. The effect of anaemia and abnormalities of erythrocyte indices on hbA1c analysis: A systematic review. Diabetologia 2015;58:1409-21.

21. Turton JA1, Andrews CM, Havard AC, Williams TC. The study of hemotoxicity of succinic chloramphenicol on the Dunkin Hartley trial rabbit Int. J Exp.Pathol 2002;83:225-38.
22. Lubran MM. Hematologic Side Effects of Drugs.Annals of Clinical and Laboratory Science. Vol. 19. Torrance, CA: Institute for Clinical Science, Inc.; 1989.

23. Mintzer DM, Billet SN, Chmielewski L. Drug-Induced Hematologic Syndromes Review Article. Egypt: Hindawi Publishing Corporation Advances in Hematology; 2009.

24. Bishop WM, Zubeck HM. Evaluation of microalgae for use as nutraceuticals and nutritional supplements. J Nutr Food Sci 2012;2:5-10.

25. Hoffman R, Xu M, Finazzi G, Barbui T. The polycythemias. Hoffman F, Benz EJ, Shattil SJ, editors. Hematology: Basic Principles and Practice. $5^{\text {th }}$ ed. Ch. 68. Philadelphia, PA: Churchill Livingstone; 2009.

26. Morkis IV, Farias MG, Rigoni LD, Scotti L, Gregianin LJ, Daudt LE, et al. Assessment of immature platelet fraction and immature reticulocyte fraction as predictors of engraftment after hematopoietic stem cell transplantation. Int J Lab Hematol 2015;37:259-64.

27. Ryan DH. Examination of Blood Cells. Lichtman MA, Gipps TJ, Seligsohn U, Gaushansky G, Prchal JT, editors. Williams Hematology. $8^{\text {th }}$ ed. Ch. 20. New York: McGraw-Hill; 2010.

28. Marks PW, Glader B. Approach to Anemia in the Adult and Child. Hoffman F, Benz EJ, Shattil SJ, editors. Hematology: Basic Principles and Practice. $5^{\text {th }}$ ed. Ch 34. Philadelphia, PA: Churchill Livingstone; 2009. 